\title{
AN ANALYSIS OF VENTILATORY VOLUMES IN PREGNANCY
}

\author{
JAMES H. KeRR, M.A., M.B., B.CHIR., F.R.C.P.(C) *
}

IN A PREVIOUS PAPER, the results of a study of bronchopulmonary resistance in pregnancy were presented. ${ }^{1}$ Three groups of women were studied and corresponding measurements of their ventilatory volumes were made whenever the resistance was estimated. Thus, this paper.presents, in addition to normal pregnancy readings, readings for two other small series of subjects, which were determined by the exigencies of a concurrent experiment. Originally it was hoped that the twin studies would produce results from which some definite correlation could be deduced, but, as will be mentioned later, this did not come about.

In each group, the method of study was as folows. On each attendance, at monthly intervals at the antenatal clinic, the women were allowed to rest as long as was feasible under the circumstances. Then, after their routine obstetric examination was completed, the ventilatory studies were made. All recordings were made with the patient in the supine position and a Collins 9-litre respirometer was used to make the measurements. Owing to the unreliability of some subjects and other fortuitous circumstances, strict adherence to the monthly schedule was not possible, so that readings were taken at other intervals. For this reason, the final record shows averages of results obtained at weekly intervals, during labour (ap), and immediately postpartum ( $\mathrm{pp}$ ).

In order to express the results in a comparative fashion, the vital capacity of each subject was calculated on the basis of the tables of Baldwin et al.,2 using the patient's height and age. These criteria were chosen as they would be unaffected by the pregnancy; other methods using weights and surface area would be dependent on measurements that would have to be given by the patient in retrospect and would thus be unreliable.

For each recording made with a patient, the results are expressed as a percentage of that particular patient's measured vital capacity, the measured vitality capacity itself being expressed as a percentage of the calculated vital capacity.

At least two recordings were made of each parameter on each occasion and, where applicable, the greater value was taken.

The first group and of 25 women who showed no evidence of pre-eclamptic toxaemia during the period of observation. One, however, developed toxaemia and convulsed immediately postpartum. The figures obtained are shown in Table I. The vital capacity shows little deviation from the calculated normal; although never exceeding 100 per cent, the range 94 to 100 per cent shows a remarkable constancy throughout the period of observation. The lung volumes demonstrate a decrease in expiratory reserve volume to about half the normal value, but there appears to be a compensatory increase in inspiratory reserve volume, the tidal volume remaining about the 20 per cent mark as previously

${ }^{\circ}$ Department of Anaesthesia, University of Toronto, Toronto, Ontario. 
TABLE I

Lung Vouumes in Pregnancy

\begin{tabular}{|c|c|c|c|c|c|c|c|c|c|}
\hline & Week of pregnancy: & 34 & 35 & 36 & 37 & 38 & 39 & ap & $\mathrm{pp}$ \\
\hline$V_{\iota}$ & $\begin{array}{l}\mathrm{N} \\
\mathrm{NH} \\
\mathrm{T}\end{array}$ & $\begin{array}{l}17 \\
23 \\
25\end{array}$ & $\begin{array}{l}14 \\
15 \\
18\end{array}$ & $\begin{array}{l}14 \\
23 \\
19\end{array}$ & $\begin{array}{l}17 \\
21 \\
20\end{array}$ & $\begin{array}{l}14 \\
18 \\
19\end{array}$ & $\begin{array}{l}17 \\
18 \\
12\end{array}$ & $\begin{array}{l}16 \\
13 \\
20\end{array}$ & $\begin{array}{l}15 \\
19 \\
17\end{array}$ \\
\hline IRV & $\begin{array}{l}\mathrm{N} \\
\mathrm{TH} \\
\mathrm{T}\end{array}$ & $\begin{array}{l}76 \\
66 \\
68\end{array}$ & $\begin{array}{l}68 \\
70 \\
73\end{array}$ & $\begin{array}{l}78 \\
68 \\
72\end{array}$ & $\begin{array}{l}72 \\
72 \\
77\end{array}$ & $\begin{array}{l}76 \\
71 \\
75\end{array}$ & $\begin{array}{l}73 \\
71 \\
77\end{array}$ & $\begin{array}{l}71 \\
75 \\
71\end{array}$ & $\begin{array}{l}72 \\
69 \\
73\end{array}$ \\
\hline ERV & $\begin{array}{l}\mathrm{N} \\
\mathrm{N} H\end{array}$ & $\begin{array}{r}7 \\
11 \\
7\end{array}$ & $\begin{array}{r}18 \\
15 \\
8\end{array}$ & $\begin{array}{l}8 \\
9 \\
9\end{array}$ & $\begin{array}{r}11 \\
7 \\
3\end{array}$ & $\begin{array}{r}10 \\
11 \\
6\end{array}$ & $\begin{array}{l}10 \\
11 \\
11\end{array}$ & $\begin{array}{r}13 \\
12 \\
9\end{array}$ & $\begin{array}{l}13 \\
12 \\
10\end{array}$ \\
\hline$f$ & $\begin{array}{l}\mathrm{N} \\
\mathrm{T}\end{array}$ & $\begin{array}{l}17 \\
10 \\
17\end{array}$ & $\begin{array}{r}15 \\
12 \\
6\end{array}$ & $\begin{array}{l}16 \\
11 \\
13\end{array}$ & $\begin{array}{l}15 \\
10\end{array}$ & $\begin{array}{l}17 \\
11 \\
12\end{array}$ & $\begin{array}{l}17 \\
12 \\
16\end{array}$ & $\begin{array}{r}16 \\
? \\
14\end{array}$ & $\begin{array}{l}16 \\
12 \\
14\end{array}$ \\
\hline$V_{\mathrm{c}}$ & $\begin{array}{l}\mathrm{N} \\
\mathrm{NH} \\
\mathrm{T}\end{array}$ & $\begin{array}{l}94 \\
91 \\
99\end{array}$ & $\begin{array}{r}95 \\
98 \\
119\end{array}$ & $\begin{array}{r}100 \\
195 \\
11\end{array}$ & $\begin{array}{r}99 \\
80 \\
125\end{array}$ & $\begin{array}{r}95 \\
90 \\
108\end{array}$ & $\begin{array}{r}98 \\
98 \\
109\end{array}$ & $\begin{array}{r}99 \\
104 \\
103\end{array}$ & $\begin{array}{r}98 \\
92 \\
109\end{array}$ \\
\hline$\dot{V}_{\mathrm{o}}$ & $\begin{array}{l}\mathrm{N} \\
\mathrm{NH} \\
\mathrm{T}\end{array}$ & $\begin{array}{l}82 \\
86 \\
74\end{array}$ & $\begin{array}{l}77 \\
58 \\
81\end{array}$ & $\begin{array}{l}77 \\
73 \\
52\end{array}$ & $\begin{array}{l}82 \\
82 \\
74\end{array}$ & $\begin{array}{l}77 \\
72 \\
71\end{array}$ & $\begin{array}{l}76 \\
72 \\
76\end{array}$ & $\begin{array}{l}77 \\
84 \\
74\end{array}$ & $\begin{array}{l}75 \\
74 \\
69\end{array}$ \\
\hline
\end{tabular}

$\mathrm{N}$ : Normal pregnant women. NH: Normal plegnant women taking an antihistamine. $\mathrm{T}$ : Women with mild pre-eclamptic toxaemia on varied forms of treatment. $V_{\mathrm{T}}$ : Tidal volume. $V_{\mathrm{C}}$ : Vital capacity. $V_{C}$ : Timed vital capacity, first second. IRV: Inspiratory reserve volume. ERV: Expiratory reserve volume. $f:$ Frequency of ventilation (respiratory rate).

observed by Cugell. ${ }^{3}$ This loss of expiratory reserve volume is not demonstrated by Cugell, his figures showing little difference from the non-pregnant values. Non-pregnant values for these volumes in patients of the same age range as the ones here studied are given as of the order of, inspiratory reserve volume, 63 per cent; tidal volume, 17 per cent; expiratory reserve volume, 20 per cent. ${ }^{*}$ The loss of expiratory reserve volume in this group of patients is probably due to the position in which the measurements were made. The timed vital capacity showed a general but small decrease, compared with the gennerally accepted nonpregnant normal of 83 per cent in the first second.

The second group of patients was again comprised of normal pregnant women who were given an antihistamine during the last month of their pregnancy. There were 13 women in the group. The figures obtained show no essential difference from those in the unmedicated group, although some depression of respiratory frequency is noted. As this depression existed before the antihistamine therapy began, the drug cannot be indicted for producing the effect. It will be noted that the slower rate is compensated by a rise in tidal volume, maintaining roughly the same minute volume. There is a similar, and slightly larger, average decrease in the timed vital capacity with, as in any small series, a larger variation from week to week. The purpose in using antihistamine (Pyribenzamine) is outlined in the paper on bronchopulmonary resistance in pregnancy. ${ }^{1}$

The third, but small, group of patients, all showing evidence of pre-eclamptic toxaemia, consisted of 9 women. Each of the patients was receiving some form 
of therapy. There is no significant deviation from the results of the first two groups in the subdivisions of the lung volumes and the timed vital capacity. It is, however, notable that the vital capacity from the 35th week onward is constantly in excess of 100 per cent of the calculated normal. It will be appreciated that one subject giving high figures in so small a series would give a falsely high average to the whole group; but, in this group, each patient's results, taken individually, showed the same tendency. It will be recalled that this same group of patients was that in which the higher readings of bronchopulmonary resistance were found. The meaning, or significance, of these observations cannot be determined from the small number of observations made.

\section{SUMMARY}

Ventilatory volumes in pregnant women have been recorded in three groups: normal pregnant women, normal pregnant women taking antihistamine, and women with mild pre-eclamptic toxaemia receiving a variety of forms of treatment. With the exception of some loss of expiratory reserve volume, the parameters measured show no change from the calculated normal for non-pregnant women of the same age and height.

\section{RÉSUMÉ}

Nous avons étudié les volumes respiratoires chez des femmes enceintes de trois différents groupes : chez des femmes enceintes en bonne santé, chez des femmes enceintes absorbant des substances antihistaminiques et chez des femmes enceintes prenant toutes sortes de médicaments à cause de signes pré-éclampsiques. A part une légère diminution du volume expiratoire de réserve, notre étude nous donne des résultats comparables à ceux que nous avons trouvés chez des femmes non enceintes du même âge et de la même taille.

\section{REFERENCES}

1. KerR, J. H. Bronchopulmonary Resistance in Pregnancy. Canad. Anaesth. Soc. J. 8: 347 (1961).

2. Baldwin, E. DeF.; Cournand, A.; \& Ruchards, D. W. Pulmonary Insufficiency I. Physiologic Classification, Clinical Methods of Analysis, Standard Values in Normal Subjects. Medicine 27: 243 (1958).

3. Cuget., D. W., et al. Pulmonary Function in Pregnancy 1. Serial Observations in Normal Women. Am. Rev. Tuberc. 67: 568 (1953).

4. Monse, M. \& HYde, H. As quoted in: Handbook of Respiration. National Academy of Sciences, National Research Council, Philadelphia. Philadelphia: W. B. Saunders Company (1958). 